\title{
Predicting Forest Understory Vegetation Types for Wildlife Management*1 - A Case Study for Japanese Serow (Caricornis crispus ) protection area in the Upper Miya River Basin, Mie Prefecture-
}

\author{
Tsuyoshi Yoshida*2.3, Tetsurou Morita*2, Ko Nagase*2 and Kazuhiro Tanaka*2
}

\begin{abstract}
This paper proposes a simple model to use in mapping forest understory vegetation types. Cartographic modeling, with the aid of GIS (Geographic Information System) technologies, was used for this study. Understory vegetation maps were produced by GIS-based prediction, and the result was applied to the analysis of the Japanese serow (Caricornis crispus) protection area in the upper Miya River Basin, Mie Prefecture, Japan. We used a simple boolean logic known as crosstab with a raster-based GIS. Our procedure and approach were focused on verification and effective use of what resource managers already know. The existing information on forest ecosystems, which included soil moisture, bioclimate, and overstory vegetation types, was used to predict forest understory vegetation. The results of our study showed there were various forest understory stratum types (bamboos, ferns, shrubs, and lower tree layers) in the species' protection area, and these varieties were considered to be preferred diet sources for serows.
\end{abstract}

Keyword: forest understory vegetation, GIS, cartographic modeling,

\section{INTRODUCTION}

Forest ecosystems are often the focus of wildlife management (Hunter 1990). Managing and planning forestlands for wildlife in general involves maintaining and creating forest environments that accommodate the habitat requirements of the species of interest (MANNAN et al., 1994). Effective management of wildlife therefore largely depends on understanding species habitat needs (C al., 1993; Yoshida et al., 1998). Forest ungulate species such as sika deer (Cervus nippon) and Japanese serow (Caricornis crispus) are primary examples of species associated with various habitat-related factors of the forests. Among various factors in forest management, understory vegeta-

${ }^{* 1}$ Part of this paper was presented at the GISA Conference in Tokyo 1999.

${ }^{*}$ Faculty of Agriculture, Kyoto Prefectural

University, Sakyo, Kyoto, 606-8522.

${ }^{* 3}$ JSPS Research Fellow tion is probably the most significant for many wildlife species, because forest understory vegetations offer forage for some species and protective cover for many species (HAyes et al., 1997). The types, richness, height, and available nutrients of understory vegetation determine the preferred habitats of wildlife species like serow and deer in Japan.

Forest scientists and managers have used the relationship between terrain, climate, moisture, and vegetation to map forest communities (BOLSTAD et al., 1998). In addition, landscape models that consider spatial properties such as plant cover have proven "useful" to manage natural resources (Ostendorf and Reynolds, 1999). Nevertheless, studies using the forest landscape-level approach to address resource issues in Japan are still limited, because ecological data such as digital wildlife habitats at the landscape level are not fully available for the diverse needs of natural resource management (YosHida et al., 1998).

Japanese natural resource managers are certainly required to prepare forest and wildlife habitat data. However, DAvis et al. (1990) indicates that it is unrealistic to 
postpone action to preserve wildlife diversity until "complete" information is collected. Researchers must make effective use of what they already know, while they are expanding their knowledge base (DAvis et al., 1990). Herein, we propose the use of existing information from phytosociological studies and GIS (Geographic Information System) technologies to predict forest understory vegetation types of the upper Miya River Basin in Mie Prefecture, Japan. We believe this study is a necessary precursor to estimating the diversity of the region and stimulating further spatial dynamics work and management efforts for forestry and wildlife, particularly Japanese serow. Local governments and the Environmental Agency of Japan (EAJ) have been actively collecting information on the ungulate's habitat and vegetation. Accumulation of these biological or geographical data makes its possible for us to map preliminary understory vegetation types for serow management. The objective of this paper is thus to describe an alternative mapping approach and to produce preliminary maps of forest understory vegetation types for future use in serow habitat analyses and forest management.

\section{FUNCTION OF FOREST UNDERSTORY}

HAYEs et al. (1997) indicates that increased understor$\mathrm{y}$ forage promotes use of thinned stands by ungulates in the Pacific Northwest, U.S.A. MAEJI et al. (1999) investigated the population density of sika deer on the Ohdaigahara in the Kii Peninsula among five vegetation types-open grassland, sparse mixed forest with coniferous and broad-leaved trees, dense mixed forests with coniferous and broadleaved trees, sparse coniferous forest, and dense coniferous forest. Their study indicates that population density of sika deer is the highest in the open grasslands with less than $20 \%$ crown cover, because the deer tend to feed on a dominant ground cover of Sasa bamboo grasses (Sasa nipponica). The deer may browse on bark, and cause dieback of overstory trees (Sekine and SATo, 1992; MAEJI et al., 1999). However, overstory vegetation dieback is common in the Ohdaigahara in which forest understory vegetation is already overgrazed by the deer, or winter snow lies higher than the ground vegetation level. Understory vegetation is the most important factor for serow as well as many other species in determining habitat preferences $\left(\mathrm{M}_{\mathrm{IE}}\right.$, $\mathrm{N}_{\text {ara }}$ and Wakayama Prefectures Education Committees, $1989 ; 1994)$. The tooth arrangement of serow is notsuited for browsing large woody plants (KUDO, 1996). There are no canine teeth in the upper jaw of serow, so a serow can only take in vegetative matter by its molar teeth. The main food sources of serow therefore are annual or perennial herbs and twigs of woody shrubs or lower tree layers (KuDO, 1996).

In addition, a well-developed understory provides cover for other wildlife such as birds that nest on the ground including species of juncos (Junco spp.), warbler (Wilsonia spp.), and thrushes (Turdas spp.) in the Pacific Northwest, U.S.A. (HAYEs et al., 1995; 1997). Abundance of some species of small mammals that are prey for reptilian, avian, and mammalian predators is also positively related to understory vegetation (herbs and shrubs) and coarse woody debris (CAREY and Johnson, 1995). Based on these previous studies, it is probably reasonable to assume that the habitats of many wildlife species including Japanese serow in the central Kii Peninsula are highly dependent on understory vegetative composition. It is consequently important for foresters and wildlife managers to map forest understory vegetation for the future protection of both wildlife species and the forest ecosystem.

\section{STUDY AREA}

The study area is in the upper Miya River Basin. Part of the area is known as the Ohsugidani Valley, which is located in the west part of Mie Prefecture (Fig. 1). The Miya River drains its water from Mt. Hidegatake, on the border of Nara and Mie Prefectures. The highest mountains in the Basin are over $1,600 \mathrm{~m}$ on the prefectures' border. The area, ranging from $1,600 \mathrm{~m}$ to $300 \mathrm{~m}$ in elevation, includes rich natural forests such as sub-alpine, cool temperate and warm temperate forests. This study area is also well-known for its heavy rainfall. Annual precipitation averages over $4,000 \mathrm{~mm}$. The basin therefore is a habitat for 23 species of mammals, 46 species of birds, 20 species of reptiles and amphibians, 1,827 species of arthropods, and 943 species of vascular plants (TAKEDA, 1998).

The Ohsugidani Valley Forest Ecosystem Preserve is a part of the study area. The area is a deep V-shaped valley with strata comprising sand stone, shale, chert, and limestone, where it is a part of the Chichibu Geology Zone (Kume, 1999). The Ohsugidani National Forest and a part of Yoshino-Kumano National Park are also included in the study area.

In recent years, the area west of Mt. Hidegatake, which is known as the Ohdaigahara, has been a focal point of forest preservation because of over-browsing on virgin Touhi spruce (Picea jezoensis) by deer (Sekine and SATo, 1992). As a result many biologists and foresters are actively involved in the Ohdaigahara. The Ohsugidani Valley however is the subject of relatively few research activities related to forestry. With limited public access, forest researchers need to use alternative approaches for vegetation mapping in the study area.

\section{METHODS}

Direct observations are the traditional approach in understory vegetation mapping. Based on the 
phytosociological studies and wildlife research in the Miya River Basin, this study however developed a presumptionbased forest understory map. Differences among taxa in moisture response and growth potential interact with climate, soils and topography to produce in changes in vegetative species composition at both regional and local scales (BolstaD et al., 1998). We focused our efforts on the small landscape scale. The development of landscape-level management and conservation of forest resources has been enhanced with tools such as GIS (Forman and Godron, 1986).

Our approach was based on the model in "Special Reports on Serow Protection in the Kii Mountains, 1994" (Mie, Nara and Wakayama Prefectures Education Committees, 1994). We used GIS techniques to predict forest understory vegetation types from the following three factor maps (1) soil moisture, (2) local bioclimate, and (3) overstory vegetation. All factor maps were converted with a raster-based GIS software package, IDRISI. In this study, we used raster-based GIS, rather than vector formats, because it was more applicable for analyzing and overlaying the boolean images in the study process. Our raster pixel size was $250 \mathrm{~m} \times 250 \mathrm{~m}$, because it was compatible with the format of other natural resource digital data in Japan (Yoshida and T ANAKA, 2000). This method resulted in each GIS pixel having its own predicted understory vegetation type.

\section{PROCEDURES}

GIS procedures and cartographic modeling

GIS-based modeling approaches developed to integrate wildlife habitat concerns in forest management are relatively new (Nichols' and Ross, 1998). Forest areas with limited access require adequate indoor preparation with resource management tools such as GIS. Our procedure was to retrieve data by using rules of "boolean logic" to operate on the attributes and spatial properties (BURROUGH, 1986). Although a simple table model is available, it is possible to map and classify understory vegetation with the boolean logic, "crosstab". Its role in the cartographic model used in this study is shown in Fig. 2. The cartographic model is a graphic representation of the data and analytical procedures used for the study. Its purposes are to help the
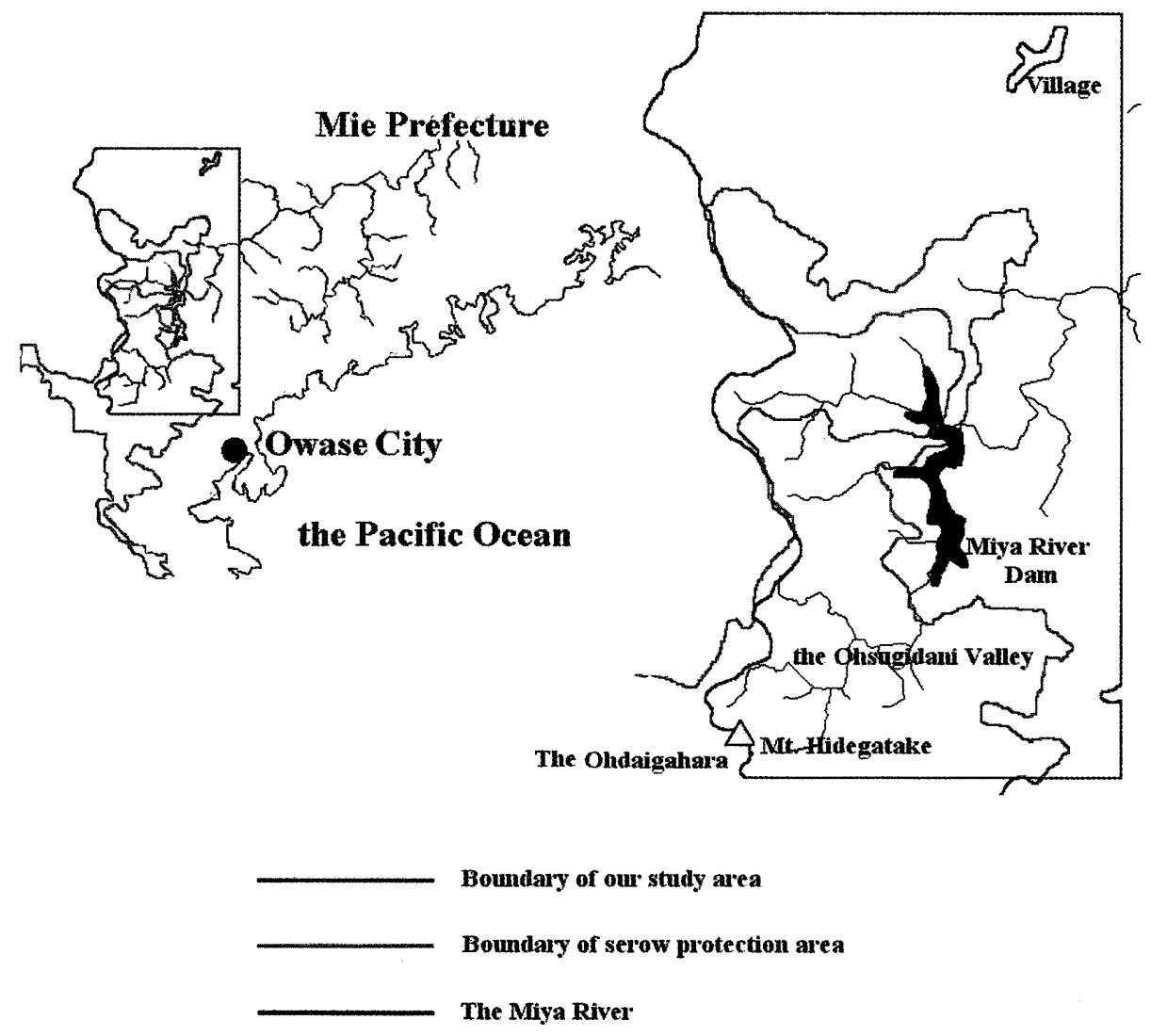

Fig. 1 The study area,upper Miya River Basin, Mie Prefecture, Japan

*Location of our study area in Mie Prefecture, Japan on left, and details of the study area on right 


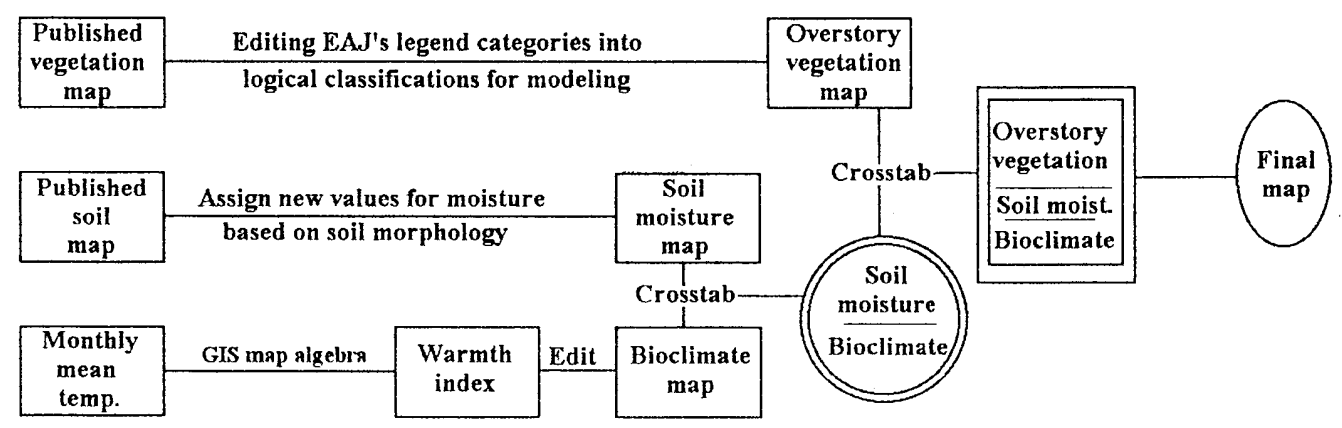

Fig. 2 Cartographic modeling process for the study

Table 1 Bioclimate types for understory vegetation

\begin{tabular}{|c|c|c|}
\hline \multirow{2}{*}{ Bioclimate } & \multicolumn{2}{|r|}{ Forest Soils } \\
\hline & Dry soil & Intermediately wet soil \\
\hline $\begin{array}{l}\text { Sub-arctic } \\
\text { forests }\end{array}$ & & $\begin{array}{l}\text { [Picea jezoensis] Carex fernaldiana, } \\
\text { Sasa nipponica, Dryopteris expansa }\end{array}$ \\
\hline $\begin{array}{l}\text { Cool temp. } \\
\text { forests }\end{array}$ & $\begin{array}{l}\text { [Tsuga sieboldii }] \\
\text { Rhododendron degronianum }\end{array}$ & 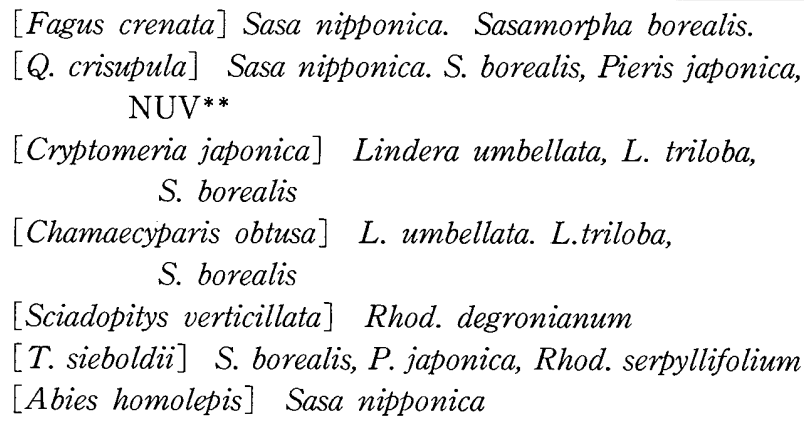 \\
\hline $\begin{array}{l}\text { Warm } \\
\text { temp. } \\
\text { forests }\end{array}$ & $\begin{array}{l}\text { [Castanopsis cuspidata] } \\
\text { Gleichenia japonica } \\
\text { [Chamaecyparis obtusa] } \\
\text { Rhod. degronianum, } \\
\text { Dicranopteris linearis } \\
\text { [Pinus densiflora] D. linearis } \\
\text { [Quercus phillyraeoides] } \\
\quad \text { Myrsine sequinii } \\
\text { Acer distylum } \\
\text { [Cryptomeria japonica }] \text { G. japonica* }\end{array}$ & $\begin{array}{l}\text { [Castanopsis sieboldii] Cleyera japonica, } \\
\text { Trachelospermum asiaticum } \\
\text { [Castanopsis cuspidata] Cley. japonica, NUV** } \\
\text { [Q. acuta] P. japonica, Arachniodes sporadora } \\
\text { [Q. gilva] Symplocos glauca } \\
\text { [Q. salicina] A. sporadora, NUV** } \\
\text { [Elaeocarpus sylvestris] Polystichopsis aristata, NUV** } \\
\text { [Q. serrata] S. borealis, Rhod. macrosepalum, } \\
\quad \text { D. dichotoma, Sasa nipponica } \\
\text { [Carpinus tschonoskii] NUV** } \\
\text { [Zelkova serrata] Camellia japonica } \\
\text { [Q. acutissima] Pleioblastus chino, NUV** } \\
\text { [Chamaecyparis obtusa] G. japonica, C. japonica, } \\
\quad \text { Rhus trichocarpa } \\
\text { [Cryptomeria japonica] G. japonica, C. japonica, } \\
\quad \text { Alpina japonica } \\
\text { [Sciadopitys verticillata] S. borealis } \\
\text { [Pinus thunbergii] Eurya japonica, Miscanthus sinensis } \\
\quad \text { Ligustrum japonicum } \\
\text { [Pinus densiflora] E. japonica, R. macrosepalum } \\
\text { [Phyllostachis pubescens] NUV** }\end{array}$ \\
\hline
\end{tabular}

[ ] indicates overstory vegetation cover

${ }^{*}$ Our field observations

**NUV indicates no dominant understory vegetation

Modified from Mie, Wakayama, and Nara Prefecture Education Committees (1994) 


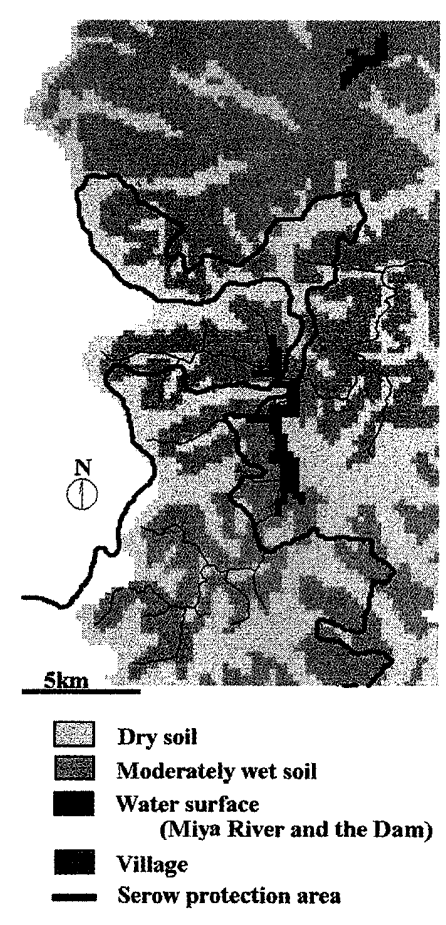

Fig. 3 Soil moisture map

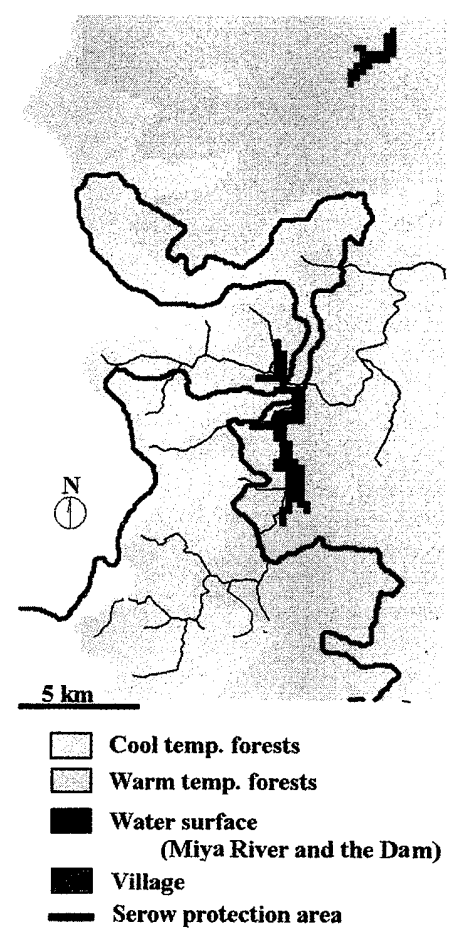

Fig. 4 Bioclimate map analyst in organizing and structuring the procedures and to identify the data needed to complete analyses.

\section{Standardized data}

For collecting understory vegetative information systematically, it is important to use standardized data. There are two sets of standardized vegetative information in Japan - Miyawaki's Japanese vegetation surveys (MIYAWAKI, 1990), and the EAJ's census reports on vegetation ( $2^{\text {nd }}$ and $3^{\text {rd }}$ National Environmental Surveys of Japan). MiE, NAra and W AKayama PRdFdcturds Education CommitteEs (1994) used their own research results from 1988 and 1989 surveys to make a model arranged in a simple table in Table 1. Based on Japan's standardized vegetative information, this table shows the presumed dominant understory vegetation based on three categories - overstory vegetation, soil moisture, and bioclimate.

\section{Soil moisture maps}

We first digitized the Geographical Survey Institute's paper-printed soil-type map of Mie Prefecture in Universal Transverse Mercator (UTM) coordinated vector files using GIS software, ArcInfo. Then, the soil-type map coverage was exported into a raster GIS format, IDRISI. This conversion process was important for assigning new values to describe soil moisture. We assigned "dry soil" for dry podzol (P-d), dry brown forest soil (B-d), and rock and lithosols ( $\mathrm{R}$ and $\mathrm{RL}$ ). The other soil types in the study area, yellow soil (Y), brown forest soil (B), kuroboku soil (A), and fine gray alluvial soil (GL-f) were translated into "moderately wet soil". These conversions were mainly based on literature reviews of soil morphology. Fig. 3 is a soil moisture map of the study area, showing two soil moisture classes.

\section{Bioclimatic regions}

Bioclimatic regions have been associated with broad changes in species composition (BAILEY, 1996). Regional bioclimates, which are typically identified by the growth of the dominant vegetation in relation to climate, are derived from a warmth index. In this study, a warmth index (WI) was calculated from mean temperature derived from the Japan Meteorological Agency's annual CD-ROM report. Monthly mean temperatures of pixels of the study area were computed with the GIS database, and the mean temperature data were used to calculate WI by GIS map algebra with the following formula:

$$
\text { Warmth Index }(W I)=\Sigma(t-5) \text {, }
$$

where $t$ is mean monthly temperature above 5 degree centigrade, summed over all 12 months.

According to KIrA (1949), five major bioclimatic regions can be identified in Japan, based on the $W I: 0<$ $W I<15$ as tundra or alpine, $15<W I<45$ as cold temperate 


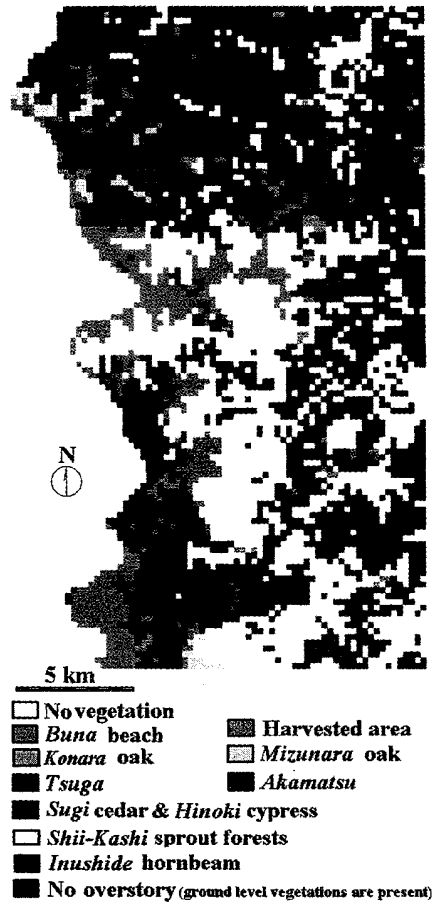

Fig. 5 Overstory vegetation map

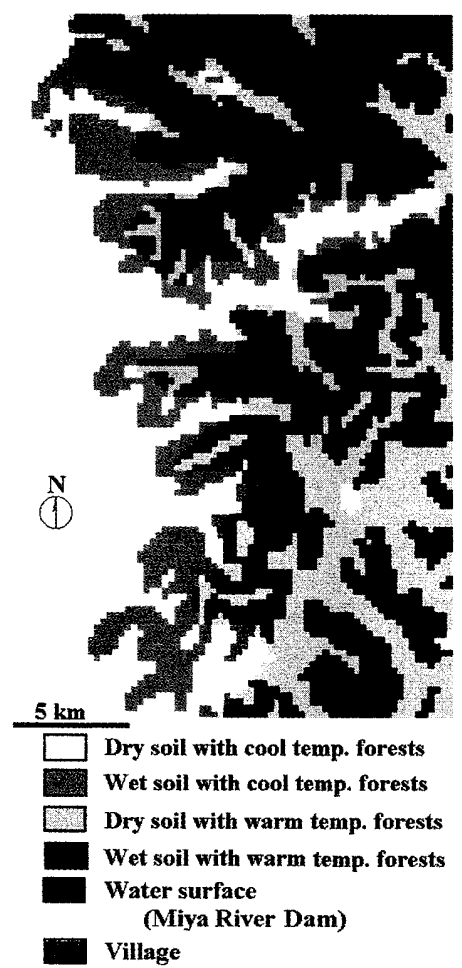

Fig. 6 Crosstab result of soil moisture and bioclimate

evergreen forests, $45<W I<85$ as cool temperate forests, $85<W I<185$ as warm temperate forests, and $180<W I<$ 240 as sub-tropical forests. Our $W I$-based calculations

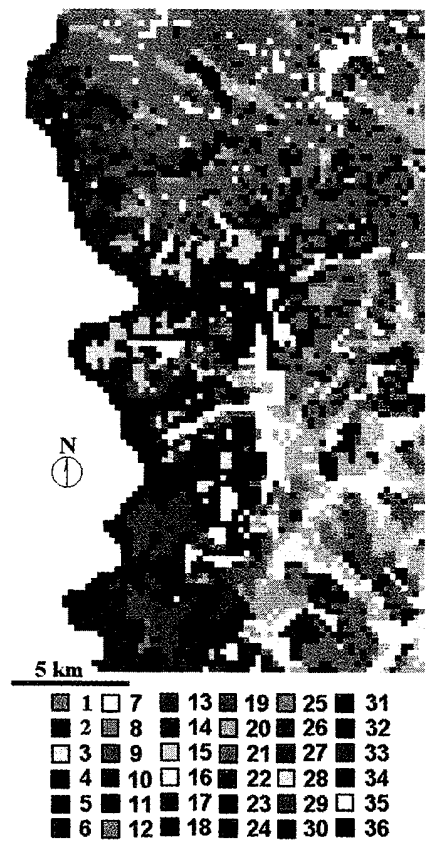

Details of classifications, refer to Table 2.

Fig. 7 Crosstab result of three factors map

showed that the study area consisted of two types of local bioclimate: "cool temperate forests" and "warm temperate forests" as shown in Fig. 4.

\section{Overstory vegetation maps}

The EAJ's vegetative classification system was reclassified into suitable categories for modeling purposes. Our classifications included (1) Inushide hornbeam (Carpinus tschonoskii), (2) Akamatsu (Pinus densiflora), (3) Konara (Quercus serrata), (4) Tsuga with Tsuga sieboldii, (5) Shii-Kashi sprout forests with species such as Castanopis cuspidata, C. sieboldii, Q. gilva, and Q. acuta, (6) Hinoki cypress (Chamaecyparis obtusa) and Sugi cedar (Cryptomeria japonica), (7) Buna beech (Fagus crenata), (8) Mizunara (Q. crispula), (9) harvested area, (10) no overstory vegetation, but understory vegetations such as bamboo (Sasamorpha borealis) and bamboo grasses (Sasa nipponica) are present. Others, for instance, the EAJ's categories of open water, agricultural area, rice paddy field, and human-used lands were classified into "no vegetation". For the modeling process, it was important to reclassify overstory vegetation into these reliable categories, so that the predictive model could be applied more adequately. The converted overstory vegetation map of the study area is shown in Fig. 5. 
Table 2 Forest understory vegetation types based on GIS crosstab

\begin{tabular}{|c|c|c|c|c|c|c|c|}
\hline $\begin{array}{l}\text { Crosstab } \\
\text { results }\end{array}$ & $\begin{array}{l}\text { Soil } \\
\text { moist }\end{array}$ & $\begin{array}{c}\text { Bio- } \\
\text { climate }\end{array}$ & $\begin{array}{c}\text { Overstory } \\
\text { vegetation type }\end{array}$ & $\begin{array}{l}\text { Dominant understory } \\
\text { Species }^{1}\end{array}$ & $\begin{array}{l}\text { Stratum } \\
\text { type }^{3}\end{array}$ & $\begin{array}{l}\text { Stratum } \\
\text { richness }\end{array}$ & $\begin{array}{c}\text { Diet } \\
\text { Source }^{5}\end{array}$ \\
\hline 1 & Dry & Cool & Carpinus laxiflora & $\begin{array}{c}\text { NA } \\
\text { (no information available) }\end{array}$ & NA & NA & NA \\
\hline 2 & Wet & $\mathrm{Cool}$ & C. laxiflora, & NA & NA & NA & NA \\
\hline 3 & Dry & Warm & C. laxiflora, & NUV & NUV & 0 & NA \\
\hline 4 & Wet & Warm & C. laxiflora, & NA & NA & NA & $\mathrm{NA}$ \\
\hline 5 & Wet & Cool & Pinus densiflora & NA & NA & NA & $\mathrm{NA}$ \\
\hline 6 & Dry & Warm & $P$. densiflora & D. linearis & $\mathrm{F}$ & 1 & PA \\
\hline 7 & Wet & Warm & P. densiflora & $\begin{array}{l}\text { Eurya japonica, } \\
R . \text { macrosepalum }\end{array}$ & $\mathrm{ES}, \mathrm{S}$ & 2 & $\mathrm{G}$ \\
\hline 8 & Dry & Warm & Quercus serrata & $\begin{array}{c}\text { NA } \\
S \text { borealis } S \text { nitponica }\end{array}$ & NA & NA & NA \\
\hline 9 & Wet & Warm & Q. serrata & $\begin{array}{l}\text { S. borealis, S. nipponica } \\
\text { R. macrosepalum, } \\
\text { D. linearis }\end{array}$ & $\mathrm{F}, \mathrm{B}, \mathrm{S}$ & 3 & B \\
\hline 10 & Dry & Cool & Tsuga sieboldii & $R$. degronianum & ES & 1 & $\mathrm{G}$ \\
\hline 11 & Wet & Cool & T. sieboldii & $\begin{array}{l}\text { Perennial grasses } \\
\text { S. borealis, Pieris japonica, } \\
\text { R. serpyllifolium, }\end{array}$ & $\begin{array}{l}\text { B, HG, } \\
\text { ES, S }\end{array}$ & 4 & PA \\
\hline 12 & Dry & Warm & T. sieboldii & NA & NA & NA & NA \\
\hline 13 & Wet & Warm & $T$. sieboldii & NA & NA & NA & NA \\
\hline 14 & Dry & Cool & $\begin{array}{l}\text { Castanopi spp. } \\
\text { sprout forests }\end{array}$ & NA & NA & NA & NA \\
\hline 15 & Wet & Cool & sprout forests & NA & NA & NA & NA \\
\hline 16 & Dry & Warm & sprout forests & $M$. sequinii, $A$. distylum & ET, DT & 2 & PA \\
\hline 17 & Wet & Warm & sprout forests & $\begin{aligned} & \text { Cleyera japonica, } \\
& \text { Tra. asiaticum, P. japonica }\end{aligned}$ & ET, V, ES & 3 & PA \\
\hline 18 & Dry & Cool & $\begin{array}{c}\text { Chamae. obtusa, } \\
\text { Cryptomeria japonica }\end{array}$ & +5 & NA & NA & NA \\
\hline 19 & Wet & Cool & $\begin{array}{l}\text { C. obtusa, } \\
\text { C japonica }\end{array}$ & $\begin{array}{l}\text { L. umbellata. L.triloba, } \\
\text { S. borealis, P. japonica }\end{array}$ & B, ES, DS & 3 & PA \\
\hline 20 & Dry & Warm & $\begin{array}{l}\text { C. obtusa, } \\
\text { C. japonica, }\end{array}$ & $\begin{array}{l}\text { D. linearis, } \\
\text { R. degronianum }\end{array}$ & F, ES & 2 & PA \\
\hline 21 & Wet & Warm & $\begin{array}{l}\text { C. obtusa, } \\
\text { C. japonica }\end{array}$ & $\begin{array}{c}\text { G. japonica, C. japonica } \\
\text { A. japonica, R. trichocarpa }\end{array}$ & $\begin{array}{l}\text { F, HG, } \\
\text { ET, DS }\end{array}$ & 4 & G \\
\hline 22 & Dry & Cool & Fagus crenata & S. borealis & B & 1 & G \\
\hline 23 & Wet & Cool & F. crenata & S. borealis, S. nipponica & $\mathrm{B}$ & 1 & G \\
\hline 24 & Dry & Warm & F. crenata & S. borealis & $\mathrm{B}$ & 1 & G \\
\hline 25 & Wet & Warm & F. crenata & S. borealis & B & 1 & G \\
\hline 26 & Dry & Cool & Quercus crispula & S. borealis & $\mathrm{B}, \mathrm{ES}$ & 2 & G \\
\hline 27 & Wet & Cool & Q. crispula & Pie. japonica, S. nipponia & B, ES & 2 & G \\
\hline 28 & Dry & Warm & Q. crispula & Pie. japonica, S. nipponia & $\mathrm{B}, \mathrm{ES}$ & 2 & G \\
\hline 29 & Wet & Warm & Q. crispula & Pie. japonica, S. nipponia & $\mathrm{B}, \mathrm{ES}$ & 2 & G \\
\hline 30 & Dry & Cool & Harvested area & $\begin{array}{l}\text { L. umbellata }{ }^{2} \text {, L.triloba } 2 \text {, } \\
\text { Stuartia monadelpa }{ }^{2} \\
\text { C. japonica }{ }^{2}, M . \text { sequinii }\end{array}$ & $\begin{array}{l}\text { DS, ET, } \\
\text { DT }\end{array}$ & 3 & G \\
\hline 31 & Wet & Cool & Harvested area & $\begin{array}{l}\text { L. umbellata }{ }^{2} \text {, L.triloba }{ }^{2} \text {, } \\
\text { Stuartia monadelpa }{ }^{2} \\
\text { C. japonica }{ }^{2}, M \text {. sequinii }{ }^{2}\end{array}$ & $\begin{array}{l}\text { DS, ET, } \\
\text { DT }\end{array}$ & 3 & G \\
\hline 32 & Dry & Warm & Harvested area & $\begin{array}{l}\text { L. umbellata }{ }^{2}, \text { L.triloba } 2,{ }^{2} \\
\text { Stuartia monadelpa }{ }^{2} \\
\text { C. japonica }{ }^{2}, \text { M. sequini }{ }^{2}\end{array}$ & $\begin{array}{l}\text { DS, ET, } \\
\text { DT }\end{array}$ & 3 & G \\
\hline 33 & Wet & Warm & Harvested area & $\begin{array}{l}\text { L. umbellata }{ }^{2} \text { L.triloba }{ }^{2} \text {, } \\
\text { Stuartia monadelpa }{ }^{2} \text {, } \\
\text { C. japonica }{ }^{2}, M . \text { sequinii }\end{array}$ & $\begin{array}{l}\text { DS, ET, } \\
\text { DT }\end{array}$ & 3 & G \\
\hline 34 & Dry & Cool & No overstory veget. & S. borealis ${ }^{3}, S$. nipponica ${ }^{3}$ & B & 1 & G \\
\hline 35 & Wet & Cool & No overstory veget. & S. borealis ${ }^{3}, S$. nipponica ${ }^{3}$ & B & 1 & G \\
\hline 36 & Wet & Warm & No overstory veget. & S. borealis ${ }^{3}$, S. nipponica ${ }^{3}$ & $\mathrm{~B}$ & 1 & $\mathrm{G}$ \\
\hline
\end{tabular}

1: For details, refer Table 1; 2: Our field observation results, 3: Documented by the EAJ, 4: F=ferns, B=bamboo and bamboo grasses, HG=evergreen herbs and grasses, $V=$ =evergreen vines, ES=evergreen shrubs, DS=deciduous shrubs, $\mathrm{S}=$ neither evergreen nor deciduous shrubs, $\mathrm{ET}=\mathrm{evergreen} \mathrm{lower} \mathrm{tree} \mathrm{and} \mathrm{tree} \mathrm{layers,} \mathrm{DT}$ $=$ deciduous lower tree and tree layers, 5 : Numbers of understory stratum types, $6: \mathrm{G}=$ majority of plants are diet source, PA= partially available 
Integrating the Data and Factor Analysis

The first step in integrating the spatial data was applying "crosstab" to two maps - soil moisture and bioclimate. The IDRIS module of crosstab created a new image based on the combination of classes in the two input images. The soil moisture map which had 2 classes (dry and moderately wet) was cross-classified with the bioclimate map (cool and warm temperate forests). Fig. 6 shows the four classes in the resulting cross-classification of soil moisture and local bioclimate maps.

Then, we again overlaid this cross-classified map to produce a second crosstab image, based on the crossclassification of the soil-bioclimate crosstab map and the actual overstory vegetation map. The second crosstab image contained a total of thirty-six classifications as shown in Fig. 7. These crosstab results were analyzed, and the corresponding relationship to the table model (Table 1) was examined with deliberation.

\section{RESULT}

The resulting thirty-six classifications from our crosstabulations, together with our prediction results for understory species, are shown in Table 2 . We used our personal field observations and literature reviews (TAKAHASHI, 1991; MiYaWAKI, 1990) to validate the results. We observed little difference between our predictions and actual understory vegetation types found in our field surveys and literature reviews. Our understory vegetation classification was evaluated by visual inspection and matching of general trends with environmental and forestry knowledge because it is difficult to statistically prove the accuracy of our prediction at this stage of study. We therefore still need to maintain surveys and terrain samplings for future analysis. It is nevertheless possible to conclude that our predicted understory vegetation map is valuable for various management purposes including serow habitat analyses.

All thirty-six classes (Fig. 7 ) could be grouped into sixteen classifications as shown in Fig. 8, based on the dominant forest understory vegetation stratum types present in the study area. We classified stratum types, for example, ferns (F) included Gleichenia japonica and Dicranopteris linearis. Bamboo and bamboo grasses (B) included species such as Sasamorpha borealis and Sasa nipponica. Vine (V), for example, was species such as Trachelospermum asiaticum. Rhododendron degronianum and Pieris japonica were major species of evergreen shrubs (ES). We classified Rhus trichocarpa, Lindera triloba, and L. umbellata in deciduous shrubs (DS). Rhododendron macrosepalum and Rhododendron serpyllifolium were species of neither evergreen nor deciduous shrubs (S). Examples of evergreen lower trees and tree layers (ET) included Myrsine sequinii and Cleyra japonica. Acer dis- tylum was the major type of deciduous tree layers (DT) in the study area. We also found multiple layers of Stuartia monadelpa (DT) by our personal observations.

The stratum richness map (Fig. 9 ) is based on the number of available understory stratum types, and shows that the richest category in our study area has four stratums. Multilayered canopies are usually considered to be good wildlife habitats for many animal species (HAYes et al., 1997).

A map of possible diet sources was derived from the previous studies on serow's plant intake (MIE, NARA and Wawkyama Prdfectures Educktion Committees, 1989; 1994). For example, understory vegetation such as Sasamorpha borealis, Sasa nipponica, and Stuartia monadelpa were considered to be diet sources for serow; but others such as Pieris japonica, and Dicranopteris dichotoma were not suited for serow diet. Based on these previous studies of serow's diet, we derived an understory diet map with two classifications - good and moderate diet sources (Fig. 10 ).

\section{DISCUSSION AND CONCLUSION}

We used these study results to identify preferred conditions of forest understory vegetation. As Table 3 indicates, a variety of stratum types are available in the forests of the serow protection area. In addition, as Table 4 and 5 show, the serow protection area in our study site seems to maintain a high level of understory diversity and source of foods for serow. As a result, based on our analyses and observations of forest understory in the study area, we conclude that the serow protection area in our study site is well suited for the species' habitat. However, for $26 \%$ of the serow protection area, or $16 \%$ of the whole

Table 3 Available stratum types in serow protection area

\begin{tabular}{cc}
\hline Dominant stratum types & $\begin{array}{c}\% \\
\text { (\% based in the study area) }\end{array}$ \\
\hline NA & $25.2(16.3)$ \\
B & $16.7(8.6)$ \\
ET, V, ES & $12.8(13.2)$ \\
B, ES, DS & $10.3(5.7)$ \\
F, HG, ET, DS & $9.8(30.0)$ \\
ET, DT & $9.3(8.6)$ \\
F, ES & $5.4(11.2)$ \\
B, HG, ES, S & $4.3(1.7)$ \\
ES & $3.1(1.4)$ \\
DS, ET, DT & $1.8(1.4)$ \\
B, ET & $1.4(1.1)$ \\
NV & $0(0.5)$ \\
ES,S & $0(0.5)$ \\
F, B,S & $0(0.1)$ \\
F & $0(0.1)$ \\
\hline
\end{tabular}




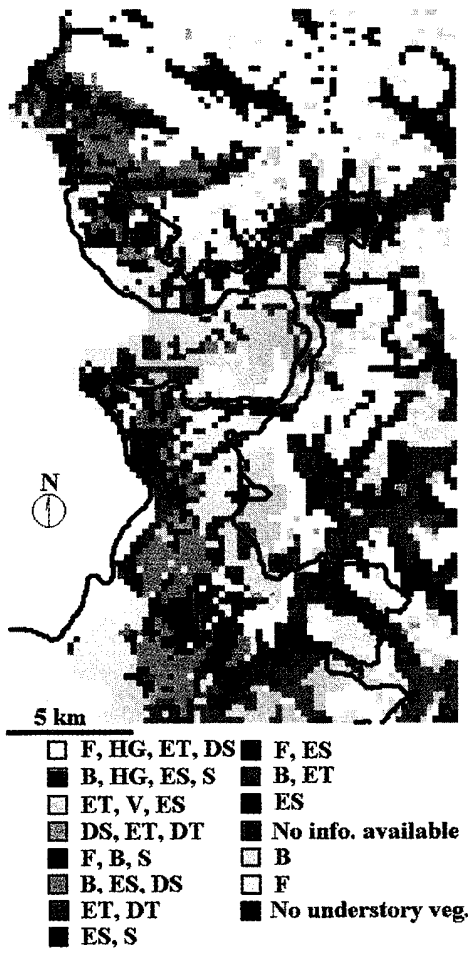

Fig. 8 Available stratum types

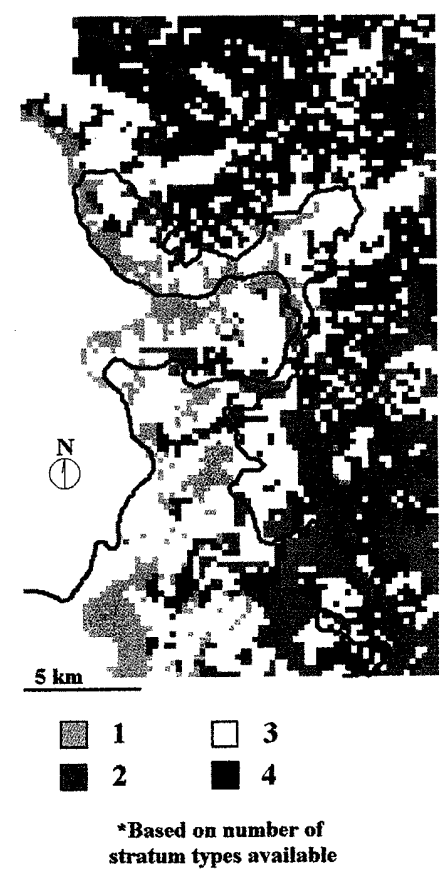

Fig. 9 Stratum richness map

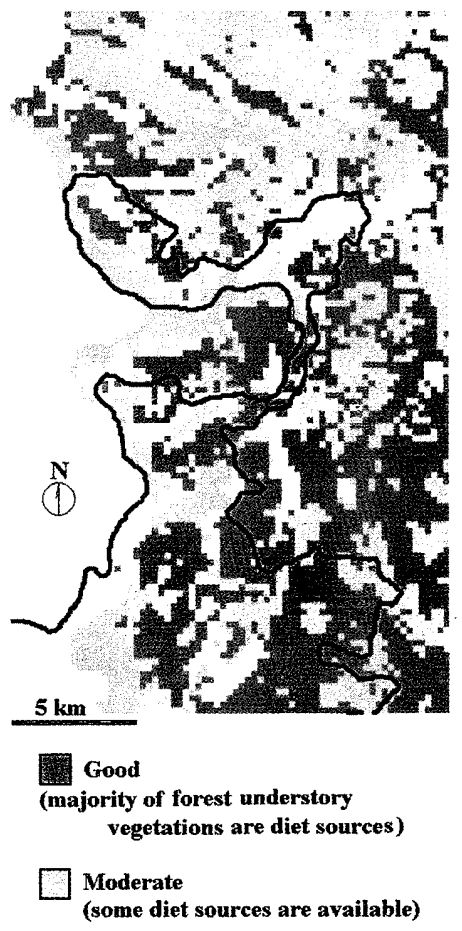

Fig. 10 Diet source availability for serow

Table 4 Stratum type richness in serow protection area*

\begin{tabular}{cc}
\hline $\begin{array}{c}\text { Numbers of stratum type } \\
\text { available }\end{array}$ & $\begin{array}{c}\% \\
\text { (\% based inthe study area) }\end{array}$ \\
\hline 1 & $23.4(11.8)$ \\
2 & $19.2(25.5)$ \\
3 & $29.7(24.5)$ \\
4 & $27.7(38.2)$ \\
\hline
\end{tabular}

${ }^{*}$ Not including NA(no information) area

Table 5 Diet source availability in serow protection area*

Diet source

(\% based in the study area)

\begin{tabular}{cl}
\hline Good & $58.3(50.4)$ \\
Moderately good & $41.7(49.6)$ \\
\hline
\end{tabular}

*Not including NA

study area, the forest understory was not examined with GIS technologies (Table 3 ).

As for forest management, thinning is indispensable for making coniferous plantations vigorous and healthy; otherwise the closed canopy does not allow the establishment of understory vegetation (TANAKA et al., 1998). Consequently, it should be noted that understory vegetation 
tends to vary with stand age, stand condition, and silvicultural practices, particularly in coniferous plantation forests. Moreover, we need to conduct continuing terrain samplings and surveys to improve accuracy in predicting understory vegetation. Vegetative sampling, however, is more strongly associated with ecological implications and researches rather than forest planning and management. Although our approach might not be of value for ecological implications, we believe that it is important to make an effective use of what foresters and resource managers already know. We therefore only focused on the management implications of understory species prediction in this study.

The results of our study indicate that a GIS-based prediction model can be an effective tool for better understanding of forest understory vegetation and serow habitat. The understory vegetation map from this study should expand the potential of GIS-based wildlife habitat analyses, especially for the ungulate species, since many GIS-based ungulate species analyses require understory vegetation maps for modeling processes. Previous studies, for example in the United States, indicate the importance of understory vegetation for various types of wildlife habitat modeling (CLARK et al., 1993). Although our approach in understory vegetation mapping was rather "coarse-filter," we believe that it developed the use of GIS and expanded our knowledge for wildlife and forest management.

We also believe that a continuous inventory program should decrease errors in modeling processes and maintain required accuracies for this type of study and mapping approach. For instance, in the United States, forest understory vegetation type is already mapped and distributed to GIS users in a compatible digital format. The CISC (Continuous Inventory of Stand Condition Program) by the U.S Department of Agriculture, Forest Service (USDA-FS) produces and maintains digital forest understory vegetation maps for almost all national forests of the United States. We strongly hope to start such a continuous inventory system for the future conservation and sustainable management of Japanese forests.

\section{ANCKNOWLEDGEMENT}

We gratefully acknowledge the financial support of the Japanese Forest Technical Association (JFTA). Hiroshi Tomida (Mie Prefecture), Akimasa TAKEDA (Mie University), Kouji Kondou (Forestry and Forest Products Institute), Hikaru Takahara, Nobuhiko Kasuya, Yoshio IsHikawA, Tatsuo Ito, Manabu IsHIZAKI, and Ko TAKAGI (Kyoto Prefectural University) provided valuable comments and helpful suggestions. We are also grateful to Masami KANEKo (Hokkaido Institute of Environmental Science) and Masaaki Maekawa (Nagano Nature Protection Institute) for helping initiate GIS analysis. We also appreciate the kind support of the Environmental Agency of Japan.

\section{LITERATURE CITED}

BAILEY, R. G., (1996): Ecosystem geography. Springer-Verlag, Berlin $204 \mathrm{pp}$

Bolstad, P., Swank, W. and Vose, J., (1998): Predicting southern Appalachian overstory vegetation with digital terrain data. Landscape Ecology 13 : 271-283

Burrough, P.A., (1986): Principles of GIS for land resources assessment. Clarendon Press, Oxford, 194pp

CAREY, A. and Johnson, M. L., (1995): Small mammals in managed, naturally young and old-growth forests. Ecol. Applications 5(2) 336-352.

Clark, J. D., DunN, J. E. and SmiTh, K.G., (1993): Multivariate models of female black bear habitat use for a geographic information system. J. Wild. Manage. $57:$ 519-526

Davis, F. W., Stoms, D. M., Estes, J. E., Scepan, J. and Scott, J. M., (1990): An information systems approach to the preservation of biological diversity. Int. J. of GIS 4 (1) : 55-78

Forman, R.T. and Gordon, M., (1986): Landscape ecology. John Wiley, New York, 620pp

Hayes, J.P., Horvath, E.G. and Hounhan, P., (1995): Townsend's chipmunk populations in Douglas-fir plantations and mature forests in Oregon Costa Range. Canadian J. of Zool. 73 : 67-73

Hayes, J.P., Chan, S. S., Emmingham, W. H., Tappeiner, J. C., Kellogg, L. D. and BAILEY, J. D., (1997): Wildlife response to thinning young forests in the Pacific Northwest. J. of For. 95 (8) :28-33

HunTER, J.C., (1990): Wildlife, forests and forestry. Prentice Hall, Englewood Cliffs, 370pp

KIRA, T., (1949): Forest types in Japan. JAFTA, Tokyo, 42pp (in Japanese)*

KuDo, J., (1996): Messages from serow's forests. NTT Publications, Tokyo, 230pp (in Japanese)*

Kume, A., (1999): Outline of field study and forests in the Miya River Basin. Proceeding of international workshop on model forests for field level applications of sustainable forest management in Mie Prefecture, Forest Agency of Japan, Tokyo, 111-124

Ostendorf, B. and Reynolds, F., (1998): A model of arctic tundra vegetation derived from topographic gradients. Landscape Ecology $13: 187-201$

Maeji, I., Yokoyama, S. and Shibata, E., (1999): Population density and range use of sika deer, Cervus nippon, on Mt. Ohdaigahara, Central Japan. J. For. Res. 4 (3) : 235-239

Mannan, R. W., Conner, R. N., Marcot, B. and Peek, J. M., (1994): Managing forestlands for wildlife (in Bookнout, T. A., (ed.) Research and management techniques for wildlife and habitats). The Wildlife Society, Bethesda, 689-721

Mie, Nara and Wakayama Prefectural Education Committees, (1989): Special reports on serow protection in the Kii Mountains1989: 92pp (in Japanese)*

Mie, Nara and Wakayama Prefectural Education Committees. (1994): Special reports on serow protection in the Kii Mountains1994: 127pp (in Japanese)*

MiYawaki, A., (1990): Vegetation of Kinki, Shibundou, Tokyo, 596pp (in Japanese with German abstracts) 
Nichols, J. M. and Rose, D. W., (1998): Predicting effects of deferred clearcutting on pine marten habitat suitability on the superior national forest. J. Jpn. For. Plan. 4 (2) : 77-82

Sekine, T. and SAto, H., (1992): The barking by sika deer, Cervus nippon Temminck, on Mt. Ohdaigahara. Jpn. J. Ecol. 42 : 241-248 (in Japanese with English summary)

TAKahashi, H., (1991): The encyclopedia of trees. Hokuryoukan Co, Tokyo, 494pp (in Japanese)

TAKEDA, A., (1998): The Ohsugidani Valley Forest Reserve. Shinrinkagaku $24: 42-45$ (in Japanese)*

TANAKA, K., Yoshida, T. and Mitsui S., (1998): Is it possible to maintain sustainable forest management in commercial scheme? Proc. Int. Symp. Global Concerns for Forest Resource Utilization:
675-684

Yoshida, T., IsHIZAKI, M. and TANAKA, K., (1998): Using GIS to Review Wildlife Habitat Information in the Kii Peninsula, Japan. Environmental Forest Sciences. Kluwer Academic Publisher, Netherlands: 345-344

Yoshida, T. and TANAKA, K., (2000): Conceptual design of a GIS-based wildlife management. Theory and Applications of GIS 8 : 121-128

*The titles are tentative translations from original Japanese titles by the authors of this paper

(Received 18 February 2000) (Accepted 2 June 2000) 